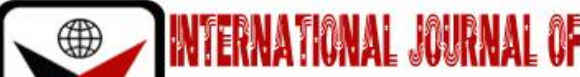

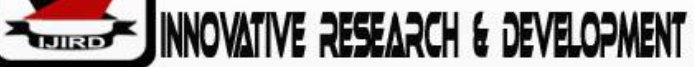

ISSN 2278-0211 (Online)

\section{Teachers' Teaching and Students' Attempts in Mathematical Proof and the Proving Process in Abstract Algebra}

\author{
Dr. Akure Mtsem \\ Chief Lecturer, Federal College of Education, Obudu, Cross River State, Nigeria \\ Dr. A. Opadeyi \\ Chief Lecturer, Department of Mathematics, Federal College of Education, Nigeria
}

\begin{abstract}
:
Proof has been considered a fundamental part of mathematical practice science from ancient times. It was introduced into the mathematics curriculum long ago and has been given an important status in teaching Euclidean geometry. There have been lots of attempts to improve students' learning of mathematical proof. If mathematical proof is given such recognition, it can help in scientific development of a society such as Nigeria in her quest for positive change, and can give a people a good name such as the one Nigeria looks forward to. However students have serious difficulties in learning proof. In such way, the researchers decided to conduct a study on 'An investigation into teachers' teaching and students' attempt in answering questions in mathematical proof and the proving process in Abstract Algebra'. The study was conducted among mathematics students in universities in North West geopolitical zone of Nigeria. The study revealed that only 38\% of Abstract Algebra questions had proof aspect, the rest were in other areas like analysis or practice. About $77.6 \%$ of students answered questions relating to proofs. This is encouraging. More students attempted proof questions in Algebra 1 with 80.1\% than they did in Algebra 2 with 75.2\%. Conclusion was made in line with these finding and recommendations were also given.
\end{abstract}

Keywords: Abstract Algebra, Proof, Mathematical Proof, Performance and Syllabus

\section{Introduction}

The word "proof" comes from the Latin probare meaning "to test". Related modern words, according to Oxford (1993) are the English "probe", "probation", and "probability", the Spanish probar (to smell or taste, or (lesser use) touch or test), Italian provare (to try), and the German probieren (to try). The early use of "probity" was in the presentation of legal evidence.

According to Bus (1997) modern proof theory treats proofs as inductively defined data structures. There is no longer an assumption that axioms are "true" in any sense; this allows for parallel mathematical theories built on alternate sets of axioms (see Axiomatic set theory and Non-Euclidean geometry for examples.

Abstract Algebra is a branch of Mathematics that deals with the nature of Algebraic structures. Where most mathematics uses numbers and equations to represent things such as the rate of return of an investment, or the movement of objects through space, abstract algebra explores new systems of equations (Miller, 2014). According to Miller (2014), those algebraic equations aren't used to represent anything in the real world, but they are fascinating to mathematicians, who, like other researchers are constantly pushing at the boundaries of what is known.

\section{Statement of the Problem}

Proof has been considered a fundamental part of mathematical practice science from ancient times. It was introduced into the mathematics curriculum long ago and has been given an important status in teaching Euclidean geometry (Dubinsky,1991).

Nigerians have made fame in mathematics through mathematical proofs. This is the press release on Chike Obi by Nigerian National News Online of February 23, 2013 (NNN, 2013): By plain brainwork and without the use of modern technological aid such as computers, world acclaimed Nigerian mathematician, Prof. Chike Obi, has given scientific proof to a 361-year old mathematical puzzle known as Fermat's Last Theorem. The science community, especially in Nigeria and other developing countries, is agog with celebration that such scholarship is coming from Africa.

Recently too, a young Nigerian lecturer, Mr. Michael Atovigba of the Benue State University, Makurdi, has made fame by proving elusive Riemanns Theory in Mathematics, a puzzle that has remained unresolved in 262 years (Nwakaudu, 2011).

Again Algebra is one of the important bodies of knowledge that the mathematically educated person should know at least at the introductory level. Indeed, a degree in mathematics always contains a course covering these concepts. Unfortunately, abstract algebra is also seen as an extremely difficult body of knowledge to learn since it is so abstract. Leron and Dubinsky (1991), in their paper "An Abstract Algebra Story", penned the following two statements, 
summarizing comments that are often heard from both teacher and student alike. Thus the question is raised: If there is something the "conscientious math professor can do about" the seemingly disastrous results in the learning of algebra, what is it that we can do? As a teacher of undergraduate mathematics, the researchers want and need to conduct an “investigation into teachers' teaching and students' understanding of mathematical proof and the proving process in abstract algebra".

\section{Research Questions}

The study sought answers to the following research questions:

1. What percentage of Nigerian University abstract algebra is made up of proofs?

2. What is the percentage of university students who answer questions from mathematical proofs in abstract algebra examinations?

3. What are other general observations that can be made from the study?

\subsection{Research Design}

The researchers adopt a case study design. The intent was to study and understand a single situation, namely teaches' teaching and students' understanding of mathematical proof and the proving process in abstract algebra.

\subsection{Sample}

Five universities from North Western Nigeria were used in the study:

- $\quad$ Federal University, Dutse, Jigawa State. FUD

- 2. Kaduna State University. Kaduna, KASU

- Bayaro University, Kano. BUK

- Usmanu Danfodiyo University, Sokoto.

- Federal University, Gusau, Zanfara State. FUG

\subsection{Instrumentation}

The researchers used Performance checklists as instrument for data collection. This article provides a checklist of questions that may help researchers determine the effectiveness of the elements, here mathematical proof, and standards they developed and whether those standards meet regulatory requirements, namely students' performance.

\section{Data Presentation, Analysis and Interpretation}

\subsection{Research Question 1} question.

What percentage of Nigerian University abstract algebra is made up of proofs? Table 1 was used to answer this

\begin{tabular}{|c|c|c|c|c|c|c|}
\hline $\mathbf{S} / \mathbf{N}$ & Name Of University & $\begin{array}{l}\text { Algebra } \\
\text { Number }\end{array}$ & $\begin{array}{l}\text { Total } \\
\text { Quest } \\
\text { Parts }\end{array}$ & $\begin{array}{l}\text { Total Quest } \\
\text { Parts With } \\
\text { Proof }\end{array}$ & $\begin{array}{c}\text { Percent } \\
\text { Quest Parts } \\
\text { With Proof }\end{array}$ & Average \\
\hline \multirow[t]{2}{*}{1} & \multirow{2}{*}{$\begin{array}{c}\text { Federal University, } \\
\text { Dutse, Jigawa State. FUD }\end{array}$} & ALGEBRA 1 & 16 & 4 & 25.0 & \multirow[b]{2}{*}{22.9} \\
\hline & & ALGEBRA 2 & 24 & 5 & 20.8 & \\
\hline \multirow[t]{2}{*}{2} & \multirow{2}{*}{$\begin{array}{c}\text { Kaduna State University. } \\
\text { Kaduna. KASU }\end{array}$} & ALGEBRA 1 & 19 & 12 & 63.2 & \multirow{2}{*}{63.2} \\
\hline & & ALGEBRA 2 & 19 & 12 & 63.2 & \\
\hline \multirow[t]{2}{*}{3} & \multirow{2}{*}{$\begin{array}{l}\text { Bayaro University, } \\
\text { Kano. BUK }\end{array}$} & ALGEBRA 1 & 14 & 4 & 28.6 & \multirow{2}{*}{24.85} \\
\hline & & ALGEBRA 2 & 19 & 4 & 21.1 & \\
\hline \multirow[t]{2}{*}{4} & \multirow{2}{*}{$\begin{array}{c}\text { Usmanu Danfodiyo } \\
\text { University, Sokoto } \\
\text { UDFU }\end{array}$} & ALGEBRA 1 & 13 & 9 & 69.2 & \multirow[b]{2}{*}{45.7} \\
\hline & & ALGEBRA 2 & 18 & 4 & 22.2 & \\
\hline \multirow[t]{3}{*}{5} & \multirow{2}{*}{$\begin{array}{c}\text { Federal University, } \\
\text { Gusau, Zanfara State. } \\
\text { FUG }\end{array}$} & ALGEBRA 1 & 12 & 6 & 50.0 & \multirow[b]{2}{*}{37.5} \\
\hline & & ALGEBRA 2 & 12 & 3 & 25.0 & \\
\hline & Total & & 166 & 63 & 38 & \\
\hline
\end{tabular}

Table 1: Percentage of Nigerian University Abstract Algebra Made Up of Proofs

From Table 1, the total sections of questions set in the two Algebra courses is 166 and the total number of question sections with aspect of proofs is 63 , which forms $38 \%$.

\subsection{Research Question 2}

'What is the percentage of university students who answer questions from mathematical proofs in abstract algebra examinations?' 
Table 2 was used to answer this question.

\begin{tabular}{|c|c|c|c|c|c|c|c|c|c|c|c|c|}
\hline \multirow[t]{2}{*}{ S/N } & \multirow[t]{2}{*}{$\begin{array}{c}\text { Name Of } \\
\text { University }\end{array}$} & \multirow[t]{2}{*}{ Algebra Type } & \multirow{2}{*}{$\begin{array}{c}\text { Total } \\
\text { No. Of } \\
\text { Stud. }\end{array}$} & \multirow[t]{2}{*}{$\begin{array}{l}\text { Total No. } \\
\text { Of Quest. }\end{array}$} & \multicolumn{7}{|c|}{$\begin{array}{c}\text { Attempts } \\
\text { Made by Students }\end{array}$} & \multirow{2}{*}{$\begin{array}{l}\text { Avrg. No. } \\
\text { That } \\
\text { Attempt } \\
\text { Proof } \\
\text { Questions } \\
\text { \& \% }\end{array}$} \\
\hline & & & & & Q1 & Q2 & Q3 & Q4 & Q5 & Q6 & Q7 & \\
\hline \multirow[t]{2}{*}{1} & \multirow[t]{2}{*}{ FUD } & ALGEBRA 1 & 12 & 7 & 12 & 12 & 7 & 11 & 4 & 6 & 8 & 11.5 (95.8) \\
\hline & & ALGEBRA 2 & 12 & 7 & 10 & 12 & 10 & 11 & 8 & 5 & 4 & $11(91.7)$ \\
\hline \multirow[t]{2}{*}{2} & \multirow[t]{2}{*}{ KASU } & ALGEBRA 1 & 72 & 6 & 72 & 66 & 12 & 70 & 14 & 42 & & $46(63.9)$ \\
\hline & & ALGEBRA 2 & 63 & 6 & 61 & 51 & 47 & 37 & 23 & 29 & & $41.3(65.6)$ \\
\hline \multirow[t]{2}{*}{3} & \multirow[t]{2}{*}{ BUK } & ALGEBRA 1 & 111 & 7 & 100 & 107 & 98 & 76 & 81 & 31 & 73 & $\begin{array}{l}103.5 \\
(93.2)\end{array}$ \\
\hline & & ALGEBRA 2 & 105 & 7 & 58 & 78 & 96 & 86 & 32 & 96 & 91 & 87 (82.9) \\
\hline \multirow[t]{2}{*}{4} & \multirow[t]{2}{*}{ UDFU } & ALGEBRA 1 & 107 & 6 & 62 & 85 & 105 & 76 & 80 & 75 & & $80.6(75.3)$ \\
\hline & & ALGEBRA 2 & 74 & 6 & 72 & 57 & 11 & 8 & 67 & 74 & & $50(67.6)$ \\
\hline \multirow[t]{3}{*}{5} & \multirow[t]{2}{*}{ FUG } & ALGEBRA 1 & 26 & 6 & 19 & 23 & 19 & 17 & 16 & 13 & & $\begin{array}{l}18.75 \\
(72.1) \\
\end{array}$ \\
\hline & & ALGEBRA 2 & 26 & 6 & 13 & 21 & 19 & 21 & 15 & 16 & & $17.67(68)$ \\
\hline & & TOTAL & 595 & 64 & 327 & 491 & 307 & 232 & 53 & 220 & & $776(77.6)$ \\
\hline
\end{tabular}

Table 2: Percentage of Students Who Answer Questions from Mathematical Proofs

From Table 2, the number of students who answered questions that contain proof aspect was underlined. In each column, such underlined numbers were added and divided by the number of times they appear in order to get average. The average was then divided by the total number of students and multiplied by 100 in order to obtain percentage in each case. In the Total raw, the average of the average was found by adding all averages and dividing by 10 (Total number of cases under consideration). The result showed that $77.6 \%$ of students answered questions relating to proofs.

\subsection{Research Question 3}

'What are other general observations that can be made from the study?

- From Table 1, it was observed that Kaduna State University took the lead in setting questions related to proofs with 63.2\%. This is followed by Usmanu Danfodiyo University, Sokoto with 45.7\%; Federal University, Gusau, Zanfara State with $37.6 \%$. Bayaro University, Kano came forth with $24.85 \%$ while Federal University, Dutse, Jigawa State came last with $22.9 \%$.

- From Table 2, it was observed that more students attempted proof questions in Algebra 1 with $80.1 \%$ than they did in Algebra 2 with 75.2\%. Precisely, the result can be summarized in Table 3.

\begin{tabular}{|c|c|c|c|c|c|c|}
\hline University & FUD & KASU & BUK & UDFU & FUG & Average \\
\hline Algebra1 & 95.8 & 63.9 & 93.2 & 75.3 & 72.1 & $80.1 \%$ \\
\hline ALGEBRA 2 & 91.7 & 65.6 & 82.9 & 67.6 & 68.0 & $75.2 \%$ \\
\hline
\end{tabular}

Table 3: Comparison of Student's Attempts between Abstract Algebra 1 \& Abstract Algebra 2

\section{Summary of Findings}

The purpose of this study was to investigate teachers' teaching and students' attempts to answer questions involving mathematical proof and the proving process in Nigeria, especially proof of abstract algebra problems. Three research questions were asked to aid the researchers to be effective in their research. The questions were:

Performance checklist was used as instrument for data collection. The result showed that:

- The total sections of questions set in the two Algebra courses was 166 and the total number of question sections with aspect of proofs was 63 , which forms $38 \%$.

- The result also showed that $77.6 \%$ of students answered questions relating to proofs.

- Kaduna State University took the lead in setting questions related to proofs with $63.2 \%$. This was followed by Usmanu Danfodiyo University, Sokoto with 45.7\%; Federal University, Gusau, Zanfara State came third with $37.6 \%$. Bayaro University, Kano came forth with $24.85 \%$ while Federal University, Dutse, Jigawa State came last with $22.9 \%$.

- $\quad$ More students attempted proof questions in Algebra 1 with 80.1\% than they did in Algebra 2 with $75.2 \%$.

\section{Recommendations}

Many people are not comfortable with abstract concepts, nor adept at abstract reasoning. However, the ability to think abstractly is a valuable asset. Abstract algebra helps develop this ability, so its teaching should be encouraged. But for this to succeed, senior secondary students must be made familiar with the standards of mathematical argumentation; in other words, they must be taught proof right from this level by introducing topics relating to abstract algebra like functions, relations, commutative property of addition and multiplication, and the symmetry group of a molecule reveals. 
University math teachers should be adept at looking at data and making plausible conjectures and generalizations. They should also teach their students to do this. This is a skill that can be learned with practice. Groups and rings provide abundant opportunities for developing this skill.

\section{References}

i. Bus, J, D. (1997). Mathematical Structures: Answering the "Why" Questions. In Dreyfus T. and Hadas N (Eds): Mathematical Proofs Retrieved January 11, 2017 from http://fcis.oise.utoronto.ca/ ghanna/educationabstracts.html

ii. Dubinsky, Ed (1991). Reflective Abstraction In Advanced Mathematical Thinking, inall, David (ed.), Advanced Mathematical Thinking, pp. 95-123, Kluwer Academic Publishers, Boston, MA. Retrieved February 27, 2016 from http://www.123helpme.com/view.asp?id=33347

iii. Leron, U. and Ed Dubinsky (1995). An Abstract Algebra Story. The American Mathematical Monthly, v. 102, No. 3, 227-242. Retrieved February 27, 2016 from: http://www.123helpme.com/view.asp?id=33347

iv. Miller, T. (2014). Solving the Future with Abstract Algebra. Retrieved February 27, 2016 from http://today.uconn.edu/2014/11/solving-the-future-with-abstract-algebra/

v. Nigerian National News Online of February 23, 2013 (NNN, 2013): Chike Obi.

vi. Nwakaudu, S. (2011). Nigerian scientist solves 262 years mathematical puzzle

vii. Features - Science. Retrieved February 23, 2013 from

http://www.ngrguardiannews.com/index.php?option=com_content\&view=article\&id=55835:nigerian-scientistsolves-262-years-mathematical-puzzle\&catid=93:science\&Itemid=608 23/02/2013 